\title{
Capabilities Overview Basic Technique Football Players SSB Ripan's U-14
}

\author{
Erik Mukhtar Erizon $^{1 *}$ and Fakhrina Hudayani ${ }^{2}$ \\ ${ }^{1,2}$ Faculty of Sports Sciences, Universitas Negeri Padang, Padang, Indonesia \\ ${ }^{*}$ Corresponding author. Email: erikerizonmukhtar@yahoo.com
}

\begin{abstract}
Problems in the study is the reduced ability of the basic techniques of soccer player SSB Ripan's U-14 Lubuk Buaya Padang. The aim of research to determine the ability of the basic techniques of passing, dribbling, shooting and heading. Type of research is descriptive, This type of research is descriptive, the population is 43 people. The sampling technique is purposive sampling with a study of 18 players from RB's U-14 Lubuk Buaya, Padang City. RESULTS: (1) the technical capability of passing, 1 category of excellent, good category 3,8 medium category, and 6 poor category. (2) the ability of dribbling techniques, 9 categories of good, moderate category 3 , category 5 people are less and less category 1. (3) the ability of shooting technique, one person category very well, either category 5,6 medium category, 4 categories less, and 2 categories less so. (4) the ability of the technique heading, 1 category of excellent, 3 good category 8 category is, 5 the poor category, and one category less so.
\end{abstract}

Keywords: Football players, capabilities

\section{INTRODUCTION}

Physical In an effort to foster good achievements, the coaching must be done from a young age or early age in order to achieve optimal performance, especially soccer. Coaching at an early age is very big influence to achieve the expected achievements. In accordance with what is explained by RI Law No. 3 Article 21 paragraph 3 (2005: 16) that: "coaching and sports development is carried out through the stages of sports introduction, monitoring, scouting and developing talent and increasing achievement".

From the description above we clearly see how important it is to carry out coaching as a process of introduction to perfect coaching in order to obtain good achievements. In an effort to foster football achievements, the existence of seeds of superior players need scientific processing so that later maximum performance will emerge at certain ages, young talented players can be found in club schools, youth organizations and villages and in Soccer Schools. Along with the emergence of the SSB is very influential and beneficial for football in Indonesia, especially in West Sumatra.

Based on the results of researchers' observations and phenomena that occur in the field as well as information from Ripan's SSB coach, that the development of the Ripan's U-14 Lubuk Buaya soccer player in Padang City has not been maximally proven in participating in the 2015 PSP trophy tournament held on
September 5, 2015 - September 20 in 2015 at the H.Agus Salim Padang Stadium only lost to the last 16, while in the 2014 PSP trophy SSB Ripan's made it to the final.

From the description of the achievements achieved by SSB Ripan's soccer player, Padang City, it is clear the problem is the decline in football playing achievements, because they often lose or fail in the matches they face, as well as in participating in soccer match events. It is not easy to achieve in football, because there are many factors that influence it. Among them, according to the author, the dominant factor influencing the achievements of the Ripan's Lubuk Buaya SSB soccer player in Padang is that they have not mastered the basic techniques of football well.

In accordance with the writer's allegations about the basic technical abilities of football players who have not been good, this can be seen from several observations and observations on the field when players do basic soccer technical training, such as passing techniques, controlling / stopping or holding the ball, dribbling or dribbling, crossing (shooting) in this case kicking the goal, and the heading technique is heading the ball with your head to pass or score against the opponent's goal. All the basic technical skills of football will be seen even more clearly in the actual appearance of players in playing, namely playing in teams in the field when participating in the PSP trophy tournament in September 2015. 
The basic technical ability of football possessed by players is certainly not easy, but players get it through training that is well programmed and refers to the principles of training, carried out continuously in the right way. According to Martin in Sfyaruddin (2011: 28) said training is "a process that is controlled in a planned manner through a material approach, methods and organizing in the process can be developed goals desired changes in the complex circumstances of achievement ability, attitude ability and behavior".

Based on the description and explanation above, then on this occasion the author is interested and wants to conduct a study related to the basic technical abilities of SSB Ripan's U-14 Lubuk Buaya player, Padang City. The truth that needs to be seen in this research is the basic technical ability of soccer players is very important so that players can play optimally with the basic techniques of good football, like a professional soccer player in the future.

\section{METHODS}

This research is in the form of descriptive, this research will describe the basic technical abilities of Ripan's U-14 Lubuk Buaya Football player in Padang City.

This type of research is descriptive, the population is 43 people. The sampling technique is purposive sampling with a study of 18 players from RB's U-14 Lubuk Buaya, Padang City.

Data collection techniques in this study were by measuring the basic technical abilities of Ripan's U14 Lubuk Buaya player in Padang City which included (passing, dribling, shooting and heading). The data analysis technique used in this study is to use descriptive analysis, with the following formula :

$$
\begin{aligned}
& \mathrm{P}=\frac{\mathrm{F}}{\mathrm{N}} \times 100 \% \\
& \text { Information : } \\
& \mathrm{P}=\text { Percentage } \\
& \mathrm{F}=\text { Frequency } \\
& \mathrm{N}=\text { Number of Samples }
\end{aligned}
$$

\section{RESULT AND DISCUSSION}

A. Result

Technical Ability to Pass, Control and Hold the Ball

Based on the description of the data about the ability to pass, control and hold the ball of SSB Ripan's U-14 Lubuk Buaya Padang City from 18 people, the data that has the ability to pass, control, and hold the ball with a score above the average group score is as much 7 people $(38.89 \%)$, and in the average group score of 5 people $(27.78 \%)$. Furthermore, for below the average group score, there are 6 people $(33.33 \%)$.
Dribbling Technique Ability (Dribbling)

Based on the description of data about the ability of the SSB Ripan's U-14 Lubuk Buaya player in Padang City which was carried out on 18 players, the player data that has the ability to dribbling (dribbling) above the average group score is as much as 10 people $(55.56 \%)$, in the average group score not one player has it and Ripan's Kota Padang SSB players who have dribbling ability (dribbling) for scores below the average group score found are as many as 8 people $(44.44 \%)$.

Shooting Technique Ability (Kicking the Ball on Goal)

Based on the data description of the shooting ability (kicking the ball into the goal) SSB Ripan's U-14 Lubuk Buaya Padang City players from 18 people, then obtained data of players who have the ability to shoot (kick the ball into the goal) above the average group score is 8 people $(44.44 \%)$, in the average group score no one has it and below the average group score of 10 people $(55.56 \%)$

Ability of Heading Technique

Based on the description of the data about the ability of heading (heading the ball) Ripan's U-14 Lubuk Buaya player from Padang City of 18 players, the player data that has the ability of heading technique (heading the ball) above the average group score is 7 people $(38.89 \%)$, the player who has the ability of heading in the average group score is 5 people $(27.78 \%)$ and below the average group score is 6 people $(33.33 \%)$.

Basic Technical Skills of Soccer Players SS Ripan's U14 Lubuk Buaya Padang

Based on the data description of the basic technical skills of RB's RIP's U-14 Lubuk Buaya player from Padang, 18 players obtained data on players who have basic technical skills above the average group score of 10 people $(55.56 \%)$, which in the average group score, there is not one person who owns it, while the players who have the basic technical skills of football below the average group score are 8 people $(44.44 \%)$.

\section{B. Discussion}

Soccer's basic technical ability is one of the elements of maturity related to football's basic technical knowledge or skills gained from education, training and experience. Experts say the ability is closely related to the physical and mental abilities that people have to carry out work, or a movement task in a sports skill, such as soccer sports skills.

In accordance with the description above, what is meant by ability here is that which is closely related to the basic technical skills of football or all activities with a ball which is fundamental to the game so that with such 
capital one can already play football. Techniques can be interpreted as a way carried out or carried out by someone in achieving an objective effectively and efficiently. Effective means the achievement of goals / targets within a predetermined time limit. Efficiency is the ability to do something or produce something without wasting a lot of material, time, and energy.

To find out the technical abilities of soccer players, SSB Ripan's U-14 Lubuk Buaya, Padang City, by carrying out several forms of ability tests which include tests of passing technical skills, controlling / stopping or holding the ball, dribbling techniques, shooting (kicking the ball into the goal) ), and heading technique (heading the ball). Then analyze the four basic types of football techniques with descriptive analysis, and the results were found that of the 18 players only 1 person is very good category namely M.Fadlin, 6 people are good categories, 6 people are medium categories, 3 people are less categories and and 2 people are very few categories, Alwan Flauna, and Randa Brasko.

Guided by the description of the basic technical skills of SSB Ripan's U-14 football player Lubuk Buaya, Padang City, it is clear that not all players have the basic technical abilities of football properly. Reality like this is a natural thing, because one's ability to master the basic techniques of football is determined by several factors including the factor of players knowledge about football in theory, football technical skills gained from training and their experience playing in applying or practicing the basic techniques of football. the.

\section{CONCLUSION}

Based on the results of research on the basic technical abilities of 18 players from RB's SSB U-14 Lubuk Buaya Padang City, only 1 person was in the excellent category, 6 people in the good category, 6 in the medium category, 3 in the less category and 2 in the less category. Then the results of each technique's ability can be seen, i.e.:

1. The ability of passing techniques, controlling and holding the ball, only 1 person in the excellent category, 3 people in the good category, 8 people in the medium category, and 6 people in the less category. This means that most players do not have the ability to pass, control and hold the ball well.

2. The ability of dribbling technique (dribbling) is not a very good category, 9 people are good categories, 3 people are medium categories, 5 people are less categories and 1 person is less categories. This means that there are still many players who have low dribbling skills.

3. The ability of shooting techniques (kicking the ball into the goal) 1 category is very good, 5 categories are good, 6 categories are medium, 4 categories are lacking, and 2 categories are very low. This means that more than a portion of the sample does not have the ability to shoot (kick at goal) properly.

4. The ability of heading technique (heading the ball with the head), only 1 person is very good category, 3 categories are good, 8 people are in the medium category, 5 people are not good at the ability of the heading.

5. Basic technical skills of SSB Ripan's U-14 Lubuk Buaya Padang City, 1 category is very good, 6 categories are good, 6 categories are medium, 3 categories are lacking and 2 categories are very low.

From the results of the test and overall we can see that from the basic football technical tests not all of the SSB Ripan's U-14 Lubuk Buaya players in Padang City are in the good category in terms of mastering the basic techniques of passing, control, dribbling, shooting and heading. This shows that the SSB Ripan's U-14 Lubuk Buaya player in Kota Padang still has unsatisfactory basic technical skills.

Therefore, the desired performance has not been achieved, because the mastery of good basic techniques in football will determine the achievements. The more a basic technique is mastered the higher the achievement achieved, and the lower the basic technique possessed the lower the achievement.

\section{REFERENCES}

[1] Sugiyono, 2008. Metode Penelitian dan pendidikan. Bandung: Alfabeta

[2] Syafruddin, 2011. Ilmu Kepelatihan Olahraga. Padang: Fakultas Ilmu Keolahragaan UNP.

[3] Winarno. 2006. Tes Keterampilan Olahraga. Malang: Laboratorium Jurusan Ilmu Keolahragaan Fakultas Ilmu Pendidikan Universitas Negeri Malang.

[4] Yusuf. 2005. Metodologi Penelitian. Padang: UNP Press. 